УДК 633.111 .5

(C) 2012

Нінієва А. К., молодший науковий співробітник

Інститут рослинництва ім. В. Я. Юр'єва НААН

\title{
УСПАДКУВАННЯ ОЗНАК ПРОДУКТИВНОСТІ КОЛОСА ГІБРИДАМИ СПЕЛЬТИ ЯРОЇ (T. SPELTA L.) ІЗ ПШЕНИЦЕЮ М'ЯКОЮ ЯРОЮ
}

\section{Рецензент - кандидат сільськогосподарських наук Н. В. Кузьмишина}

\begin{abstract}
Встановлені рівні прояву і характер успадкування ознак продуктивності у ранніх поколіннях гібридів між спельтою ярою та пшеницею м'якою ярою в порівняні з батьківськими формами, взаємозв'язок між ознаками, вплив на них погодних умов. $B F_{1}$ гібридів частіше за все мала місие гібридна депресія. В $F_{2}$ рослини, щзо перевищують краму батьківську форму за усіма ознаками колоса, виявлені в усіх комбінаціях у рік, більш сприятливий за умовами зростання.
\end{abstract}

Ключові слова: спельта, гібриди, продуктивність колосу, успадкування, кореляція

Постановка проблеми. Пшениця спельта (T. spelta L.) є одним із найдавніших видів роду Triticum [9]. Інтерес до їі вирощування зростає у світі й на Україні. У країнах західної Свропи (Німеччина, Бельгія, Швейцарія, Франція, Іспанія) спельту вирощують на площі понад 100 тис. га, передусім, завдяки високим дієтичним і поживним властивостям зерна: високому вмісту білка $(14,5-17,3 \%)$, багатого лізином $(3,0 \%)$, фенілаланіном (4,7\%), триптофаном (1,4\%) [8].

Значному поширенню спельти у виробництві перешкоджає іiі порівняно низька урожайність i низка морфологічних характеристик, негативних у виробничому відношенні, зокрема ламкість колоса і важкий вимолот [2]. Причина полягає у тому, що існуючі форми спельти є переважно продуктом народної селекції, й лише в останній час іiі селекція ведеться сучасними методами, включаючи гібридизацію та біотехнологічні заходи. Тому на даному етапі сорти спельти не можуть конкурувати з сортами пшениці м'якої, створеними інтенсивною і тривалою селекцією.

Аналіз останніх досліджень i публікацій, у яких започатковано розв'язання проблеми. Селекція спельти активно ведеться у країнах Свропи - Німеччині, Австрії, Швейцарії, Сербії та ін., в Австралії, Канаді. У Росії в останні роки методом індивідуального добору створено і внесено у Державний реєстр сорт спельти озимої Алькоран з гібридної популяції від схрещування сорту спельти Altgold Rotkorn (Швейцарія) 3 сортом пшениці м'якої Avalon (Великобританія) [5].

У країнах Європи селекційна робота ведеться переважно зі спельтою озимою. Нашими дослідами встановлено, що умови перезимівлі у східній частині Лісостепу України є складними і не гарантують одержання урожаю. Тому більш надійною культурою є спельта яра. Проте для іiі впровадження у виробництво необхідно селекційним шляхом підвищити урожайність. Генетичним джерелом для цього $є$ сучасні сорти пшениці м'якої.

Низкою досліджень [6] встановлений зв'язок між проявом ознак у ранніх поколіннях гібридів і частотою утворення селекційно цінних форм у більш пізніх поколіннях, отже, можливість прогнозувати успіх селекції.

Мета і завдання досліджень. У зв'язку з вище вказаним, метою наших досліджень $\epsilon$ встановити прояв та успадкування ознак продуктивності у ранніх поколіннях гібридів між спельтою та м'якою пшеницею порівняно 3 батьківськими формами. Для цього вирішували такі завдання:

1) визначити рівні прояву ознак продуктивності колосу у батьківських форм - спельти ярої та пшениці м'якої ярої у роки з різними агрометеорологічними характеристиками;

2) встановити прояв та ступінь домінування ознак у рослин гібридів $\mathrm{F}_{1} \mathrm{y}$ порівнянні 3 батьківськими формами;

3) встановити частоту рослин із перевищенням кращої батьківської форми за ознаками продуктивності колосу і ступінь цього перевищення;

4) визначити взаємозв'язок між продуктивністю колоса та іiї елементами у гібридів спельти 3 пшеницею м'якою та їх батьківських форм.

Матеріал й методи досліджень. Матеріалом для дослідження були зразки спельти ярої з Національного генбанку рослин України: UA0300304 var. album, Австралія (AUS); UA0300111 var. album, Канада (CAN) та сорти пшениці м'якої ярої: Героїня (Україна, IP ім. В. Я. Юр'єва) і Sunnan (Німеччина). Тобто, батьківські форми мали різне 
географічне і генетичне походження.

Дослідження проводили впродовж 2009-2011 pp. на полях першої восьмипільної селекційної сівозміни IP ім. В. Я. Юр'єва НААН, розміщеній за 20 км на схід від м. Харкова.

Зразки спельти та пшениці м'якої висівали ручними саджалками на ділянки площею 1 м $^{2} 3$ шириною міжрядь 15 см, нормою висіву 500 зерен на $1 \mathrm{~m}^{2}$. У ході сівби використовували схему: «матір - $\mathrm{F}_{1-2}-$ батько». Аналіз структури урожаю проводили за методикою ВIP [4]. За настання повної стиглості відбирали снопи: по 25 рослин батьківських форм і всі рослини гібридів [3]. Ступінь домінування в $\mathrm{F}_{1}$ визначали за методикою Гриффінга [8], групування отриманих даних проводили згідно з методикою Beil, Atkins [7].

$\mathrm{y} \mathrm{F}_{2}$ виявляли рослини, що перевищують кращу батьківську форму за ознаками колоса. Визначали частоту перевищення (Пч) і ступінь перевищення (Пс), застосовуючи формули Г. С. Воскресенської та В. І. Шпота [1]; обидві величини визначали у відсотках.

Погодні умови у роки досліджень відрізнялися за основними метеорологічними показниками. У 2009 р. квітень був прохолодний і сухий, що негативно позначилося на густоті сходів. Протягом вегетації середньодобові температури наближалися до багаторічних значень, а кількість опадів була нижчою. Це створило жорсткі умови для росту i розвитку рослин ярих спельти та пшениці м'якої.

У 2010 р. середньодобові температури перевищували багаторічні впродовж усього періоду вегетації. Критичні фази виходу в трубку, колосіння та цвітіння проходили за посушливих умов, що обумовило низький рівень урожайності. Сприятливий гідротермічний режим спостерігався у фазі наливу зерна.

Протягом вегетаційного періоду 2011 р. на початкових фазах росту і розвитку рослин спельти та пшениці м'якої ярої гідротермічний режим був сприятливим. Однак високі показники максимальних температур у другій і третій декадах липня та першій декаді серпня негативно вплинули на проходження кінцевих фаз розвитку рослин, що негативно позначилося на формуванні урожайності.

Результати досліджень. У таблиці 1 представлені показники колосу зразків пшениці м'якої і спельти та рослин $\mathrm{F}_{1}$, отриманих за їх участі.

Батьківські форми відрізнялися за характеристиками колосу в обидва роки: у 2010 р. із жорсткою посухою до цвітіння, але сприятливими умовами наливу зерна, порівняно з посушливим упродовж усієї вегетації 2009 року.

Iз батьківських форм першої пари реципрокних гібридів (Героїня та спельта UA0300111) у 2010 р., проти 2009 р., сорт Героїня дещо зменшив довжину колосу, не змінивши кількості колосків (отже, збільшив його щільність); суттєво збільшив озерненість колосу, масу 1000 зерен і, як результат, - масу зерна 3 колосу. Спельта UA0300111 зменшила всі показники, збільшивши лише щільність колосу. Порівнюючи спельту 3 м'якою пшеницею, виявили, що у 2009 р. вона переважала за довжиною колосу і масою 1000 зерен і практично дорівнювала м'якій пшениці за масою зерна 3 колосу і кількістю колосків у колосі. У 2010 спельта поступалася м'якій пшениці за всіма показниками.

Обидва реципрокні гібриди $\mathrm{F}_{1}$ між сортом Героїня та спельтою UA0300111 у 2009 р. (порівняно 32010 р.) мало змінили довжину колосу, кількість колосків у ньому та щільність колосу, але у значно більшій мірі, ніж сорт Героїня, знизили озерненість колосу, масу 1000 зерен та масу зерна 3 колосу. Гібрид, у якого материнською формою була спельта, мав в обидва роки вищі, ніж у реципрокного гібриду, довжину колосу, кількість колосків у ньому та щільність колосу; у 2009 р. - озерненість колосу, масу 1000 зерен та масу зерна 3 колосу. У 2010 р. за останніми трьома показниками практично не спостерігалося відмінностей між обома реципрокними гібридами.

Стосовно успадкування ознак у $\mathrm{F}_{1}$ виявилося, що у 2009 р. практично за всіма ознаками спостерігалася гібридна депресія: рослини були пригніченими, порівняно 3 батьківськими формами; лише у гібрида UA0300111 / Героїня успадкування було близьким до проміжного. У 2010 р. гібридна депресія мала місце за кількістю колосків у колосі, щільністю колосу та у прямій комбінації за довжиною колосу. За озерненістю колосу, масою 1000 зерен та масою зерна 3 колосу відмічено домінування або зверхдомінування батьківської форми 3 більшим проявом ознаки - м'якої пшениці.

Із батьківських форм другої пари гібридів спельта UA0300304 за проявом ознак була в цілому близькою до UA0300111, перевищуючи іiі на 1-2 г за масою 1000 зерен. У 2010 р. вона зменшила озерненість колосу, масу 1000 зерен та масу зерна $з$ колосу і не змінила довжини колосу, кількості колосків у ньому, отже, щільності колосу. Сорт Sunnan, як і очікувалося, виходячи 3 його екотипу, досить негативно реагував на посушливі умови 2009 р. порівняно з 2010 р., 
знизивши на третину масу 1000 зерен та озерненість колосу й удвічі - масу зерна з колосу. Спельта переважала сорт Sunnan за масою 1000 зерен і масою зерна з колосу у 2009 р. і за довжиною колосу - в обидва роки; поступалася м'якій пшениці за щільністю та озерненістю колосу, масою зерна з колосу.

$\mathrm{y}$ реципрокних гібридів $\mathrm{F}_{1}$, створених за участі сорту Sunnan і спельти UA0300304 (AUS), у 2009 р. усі показники були нижчі, ніж у 2010 році. Обидва гібриди у 2009 р. показали гібридну депресію за кількістю колосків у колосі, кількістю зерен у колосі та масою зерна з колосу, у прямій комбінації за масою 1000 зерен; домінування спельти як батьківської форми з більшим рівнем прояву ознаки за масою 1000 зерен в оберненій комбінації; домінування батьківської форми 3 меншим рівнем прояву ознаки: спельти за щільністю колосу, м'якої пшениці за довжиною колосу, масою 1000 зерен в оберненій комбінації. У 2010 р. мало місце зверхдомінування в обох реципрокних комбінаціях за масою 1000 зерен, у прямій комбінації за озерненістю колосу і масою зерна з колосу; проміжне або близьке до нього успадкування в обох комбінаціях за кількістю колосків у колосі, у прямій комбінації за щільністю колосу, в оберненій - за довжиною колосу і кількістю зерен у ньому; домінування спельти як форми з нижчим показником ознаки за довжиною колосу у прямій комбінації, щільністю колосу - в оберненій.

Гібриди $\mathrm{F}_{1}$ спельти не проявили гетерозису за масою зерна 3 колосу. Головний елемент продуктивності спельти, який позитивно впливає на продуктивність $\mathrm{F}_{1}$ iï гібридів із пшеницею м'якою ярою, - це маса 1000 зерен. Виявляється значний реципрокний ефект в успадкуванні ознак гібридами $\mathrm{F}_{1}$, який сильніше виражений у більш жорсткому 2009 році. До того ж за інтегрованим показником - масою зерна 3 колосу у менш жорсткому 2010 р. реципрокні відмінності мінімальні.

\section{1. Прояв і успадкування ознак колоса у рослин $F_{1}$ спельти ярої з пшеницею м'якою *}

\begin{tabular}{|c|c|c|c|c|c|c|c|c|c|c|c|c|}
\hline \multirow{2}{*}{$\begin{array}{c}\text { Гібриди, } \\
\text { батьківські } \\
\text { форми }\end{array}$} & \multicolumn{2}{|c|}{$\begin{array}{c}\text { Маса зерна } \\
\text { з колоса, } \\
\Gamma\end{array}$} & \multicolumn{2}{|c|}{$\begin{array}{l}\text { Кількість зе- } \\
\text { рен у колосі, } \\
\text { шт. }\end{array}$} & \multicolumn{2}{|c|}{$\begin{array}{c}\text { Маса } \\
1000 \text { зерен, } \\
\text { Г }\end{array}$} & \multicolumn{2}{|c|}{$\begin{array}{c}\text { Довжина } \\
\text { колоса, } \\
\text { см }\end{array}$} & \multicolumn{2}{|c|}{\begin{tabular}{|c} 
Кількість \\
колосків \\
у колосі, шт.
\end{tabular}} & \multicolumn{2}{|c|}{$\begin{array}{l}\text { Щільність } \\
\text { колоса, } \\
\text { шт. /10 см }\end{array}$} \\
\hline & $\begin{array}{c}2009 \\
\text { p. }\end{array}$ & $\begin{array}{c}2010 \\
\text { p. }\end{array}$ & $\begin{array}{c}2009 \\
\text { p. }\end{array}$ & $\begin{array}{c}2010 \\
\text { p. }\end{array}$ & $\begin{array}{c}2009 \\
\text { p. }\end{array}$ & $\begin{array}{c}2010 \\
\text { p. }\end{array}$ & $\begin{array}{c}2009 \\
\text { p. }\end{array}$ & $\begin{array}{c}2010 \\
\text { p. }\end{array}$ & $\begin{array}{c}2009 \\
\text { p. }\end{array}$ & $\begin{array}{c}2010 \\
\text { p. }\end{array}$ & $\begin{array}{c}2009 \\
\text { p. }\end{array}$ & $\begin{array}{c}2010 \\
\text { p. }\end{array}$ \\
\hline & 107 & & 10 & 1 & 260 & $\frac{15}{250}$ & 05 & & 19 & 10 & 19 & 20 \\
\hline $\begin{array}{r}\text { Гер } \\
\text { UA0 } \\
\text { (C }\end{array}$ & $\frac{14}{2,00}$ & $\frac{1,38}{0,69}$ & $\frac{10}{4,45}$ & $\frac{39}{0,60}$ & $\frac{14,0}{-5,93}$ & $\frac{35,4}{1,12}$ & $\frac{8,5}{-2,67}$ & $\frac{9,0}{5,67}$ & $-1 \frac{14}{9,00}$ & $\frac{15}{-7,00}$ & $-\frac{15}{-1,75}$ & $\frac{16}{-4,37}$ \\
\hline $\begin{array}{r}\mathrm{UAC} \\
(\mathrm{C} \\
\Gamma \mathrm{C}\end{array}$ & $\frac{39}{7,00}$ & $\frac{31}{47}$ & $\frac{16}{-3,36}$ & $\frac{38}{0,47}$ & $\frac{24,4}{2,05}$ & $\frac{34,5}{0,63}$ & $\frac{9,0}{-1,83}$ & $\frac{9,5}{5,44}$ & $\frac{17}{-7,00}$ & $\frac{17}{-3,00}$ & $\frac{18}{0,15}$ & $\frac{17}{-2,76}$ \\
\hline $\begin{array}{r}\mathrm{UA} \\
(\mathrm{C}\end{array}$ & 05 & 84 & 29 & 27 & 32,1 & 31,4 & 10,7 & 9,2 & 19 & 18 & 16 & 18 \\
\hline & 70 & & 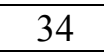 & 45 & 0,6 & 226 & 62 & 6 & 18 & 18 & 27 & 28 \\
\hline $\begin{array}{r}\mathrm{Su} \\
\mathrm{UA}\end{array}$ & $\frac{0,39}{-3,00}$ & $\frac{1,65}{1,61}$ & $\frac{20}{3,00}$ & $\frac{46}{1,12}$ & $\frac{9,5}{1,16}$ & $\frac{35,9}{15,17}$ & $\frac{6,9}{-0,64}$ & $\frac{7,0}{-0,55}$ & $-31,00$ & $\frac{17}{0}$ & $\frac{20}{-0,38}$ & $\frac{23}{0,07}$ \\
\hline $\begin{array}{r}\mathrm{UA} 0 \\
\text { (A } \\
\mathrm{Su}\end{array}$ & $\frac{0,28}{-3,71}$ & $\frac{1,33}{0,53}$ & $-\underline{9}$ & $\frac{38}{0,18}$ & $\frac{31,1}{0,54}$ & $\frac{34,7}{10,23}$ & $\frac{7,7}{-0,23}$ & $\frac{8,1}{-0,01}$ & $-3 \frac{15}{1,00}$ & $\frac{18}{0}$ & $-\underline{18}$ & $\frac{21}{-0,22}$ \\
\hline $\begin{array}{r}\mathrm{UA} 0 \\
(\mathrm{~A}\end{array}$ & 1,01 & 0,88 & 27 & 28 & 34,2 & 32,1 & 10,1 & 10,1 & 18 & 18 & 17 & 17 \\
\hline & ד ד & 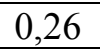 & , & U,JT & $0, \mathrm{~J}$ & 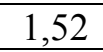 & 1,40 & 122 & 1,76 & 1,01 & 3,31 & 3,58 \\
\hline $\begin{array}{c}\text { Середнє: } \\
\text { батьки }\end{array}$ & 0,96 & 1,1 & 33 & 36 & 28,5 & 32 & 9,1 & 8,7 & 19 & 1 & 20 & 21 \\
\hline гібриди & 0,30 & 1,42 & 14 & 40 & 22,3 & 35,1 & 8,0 & 0,4 & 15 & 17 & 18 & 19 \\
\hline
\end{tabular}

Примітка: * - у чисельнику - значення ознаки, у знаменнику - ступінь фенотипового домінування (hp) 


\section{СІЛЬСЬКЕ ГОСПОДАРСТВО. РОСЛИННИЦТВО}

Виявлені відмінності в успадкуванні ознак колоса реципрокними гібридами можна пояснити різницею між цитоплазмами батьківських форм.

$\mathrm{У}$ результаті аналізу гібридів $\mathrm{F}_{2}$ виділено рослини, які перевищували кращі батьківські форми за ознаками колоса (табл. 2). Звертає на себе увагу, що у 2011 р., сприятливому на ранніх етапах розвитку рослин, хоча й посушливому у другій половині вегетації, перевищення кращої батьківської форми спостерігалось у рослин усіх чотирьох комбінацій за всіма ознаками колоса. У той же час у 2010 р. із жорсткими умовами на перших фазах вегетації і сприятливому у період наливу та формування зерна, рослини 3 перевищенням були відсутні у комбінації Героїня / UA0300111 за всіма ознаками, крім маси 1000 зерен; Sunnan / UA0300304 за довжиною колосу, UA0300304 / Sunnan за кількістю колосків і зерен у колосі. Далі частота перевищення кращої батьківської форми за масою 1000 зерен була більшою, ніж за іншими ознаками (UA0300111 / Героїня; UA0300304 / Sunnan) або, принаймні, середньою (інші дві комбінації).

Нижня та верхня межі ступеня перевищення в $\mathrm{F}_{2}$ всіх комбінацій були високими у 2011 р. за кількістю зерен у колосі, що обумовлено високою фертильністю колосків; в обох комбінаціях, де материнською формою була спельта, - за довжиною колосу; у комбінації Sunnan / UA0300304 - за масою 1000 зерен та в обидва роки - за масою зерна 3 колосу. У реципрокній комбінації UA0300304 / Sunnan найвища ступінь перевищення в обидва роки спостерігалася за довжиною колосу. В цілому найбільші частота $\mathrm{i}$ ступінь перевищення кращої батьківської форми за продуктивністю колосу спостерігалося в обидва роки у комбінації Sunnan / UA0300304, найменші - у Героїня / UA0300111.

Із метою визначення впливу окремих ознак колосу на його продуктивність були обраховані коефіцієнти парної кореляції (табл. 3). У батьківських форм та $\mathrm{F}_{1}$ їх слід розглядати як фенотипові, $\mathrm{F}_{2}$ вони у більшій мірі обумовлені генотиповими відмінностіми.

В обох сортів пшениці м'якої маса зерна 3 колосу тісно і позитивно пов'язана з озерненістю колосу і значно слабше з масою 1000 зерен, кількістю колосків у колосі і довжиною колосу, за виключенням 2009 р. у сорту Sunnan, коли зв'язок з усіма названими ознаками виявився тісним. У спельти UA0300111 в усі три роки тісним був зв'язок маси зерна 3 колосу 3 масою 1000 зерен, у 2010 p. - і 3 іншими ознаками. У спельти UA0300304 маса зерна з колосу тісно корелює $з$ кількістю колосків у колосі та його озерненістю і значно слабше - 3 масою 1000 зерен. Таким чином, характер обумовленості продуктивності колосу з боку іiі елементів у пшениці м'якої і спельти принципово не відрізняється i залежить від генотипу.

$\mathrm{У}$ рослин $\mathrm{F}_{1}$, створених за участі сорту Героїня і зразка спельти UA0300111, спостерігалася висока стабільна позитивна кореляція між масою зерна з основного колоса, з одного боку, і кількістю зерен у ньому, - 3 іншого, у прямій і оберненій комбінаціях за обидва роки досліджень $(\mathrm{r}=0,88-0,90)$. У несприятливому 2009 р. продуктивність колосу майже не залежала від маси

\section{2. Перевищення над батьківськими формами рослин $F_{2}$ спельти з пиеницею м'якою}

за ознаками колоса

\begin{tabular}{|c|c|c|c|c|c|c|c|c|c|}
\hline \multirow{2}{*}{$\begin{array}{l}\text { Ознаки } \\
\text { колоса }\end{array}$} & \multirow[t]{2}{*}{ Рік } & \multicolumn{2}{|c|}{$\begin{array}{c}\text { Героїня / } \\
\text { UA0300111 (CAN) }\end{array}$} & \multicolumn{2}{|c|}{$\begin{array}{c}\text { UA0300111 (CAN) } \\
\text { / Героїня }\end{array}$} & \multicolumn{2}{|c|}{$\begin{array}{c}\text { Sunnan / } \\
\text { UA0300304 (AUS) }\end{array}$} & \multicolumn{2}{|c|}{$\begin{array}{c}\text { UA0300304 (AUS) } \\
\text { / Sunnan }\end{array}$} \\
\hline & & Пч, \% & Пс, \% & Пч, \% & Пс, \% & Пч, \% & Пс, \% & Пч, \% & Пс, \% \\
\hline \multirow{2}{*}{$\begin{array}{c}\text { Маса зерна } \\
3 \text { колоса } \\
\end{array}$} & 010 & 0 & 0 & 13,6 & $7,5-8,6$ & 30,5 & $9,5-38,2$ & 16,7 & $4,0-5,8$ \\
\hline & 2011 & 5,0 & -25 & 19,0 & , & 0 & 6 & 21,2 & $3,0-8,7$ \\
\hline \multirow{2}{*}{$\begin{array}{l}\text { Кількість зе- } \\
\text { рен із колоса }\end{array}$} & 010 & U & 0 & 9,1 & $3,0-$ & 44 & $-13,5$ & 0 & 0 \\
\hline & 2011 & 0 & $, 5-32,2$ & 12,2 & $10,0-33,1$ & 19,5 & $5-28,7$ & 15,5 & $10,0-22,8$ \\
\hline \multirow{2}{*}{$\begin{array}{c}\text { Maca } 1000 \\
\text { зерен }\end{array}$} & 2010 & & -12 & 35 , & 5,5 & 19,8 & 7,5 & 48,1 & $3,0-22,0$ \\
\hline & 2011 & 0 & $-18,5$ & 22,0 & $8,5-15,4$ & 22,0 & $6,5-25,0$ & 38,8 & $5,0-20,4$ \\
\hline \multirow{2}{*}{$\begin{array}{c}\text { Кількість } \\
\text { колосків } \\
\text { у колосі }\end{array}$} & 2010 & 0 & 0 & 1,0 & $3,0-8,0$ & 2,0 & $3,0-5,0$ & 0 & 0 \\
\hline & 2011 & 4,0 & 3 , & 4,0 & $3,5-5,0$ & 1,0 & 0 & 5,0 & $3,0-7,0$ \\
\hline \multirow{2}{*}{$\begin{array}{c}\text { Довжина } \\
\text { колоса }\end{array}$} & 2010 & 0 & 0 & 4,0 & 更 & 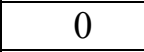 & 0 & 18,0 & $7,0-28,1$ \\
\hline & 2011 & 2,0 & $4,5-10,3$ & 8,0 & $10,0-22,0$ & 4,0 & $5,5-10,2$ & 22,0 & $8,0-33,8$ \\
\hline
\end{tabular}

Примітки: Пч - частота перевищення; Пс - ступінь перевищення 
СІЛЬСЬКЕ ГОСПОДАРСТВО. РОСЛИННИЦТВО

3. Коефіцієнти кореляції між продуктивністю колоса та ї̈ елементами у гібридів спельти з пиеницею м'якою та їх батьківських форм, 2009-2011 рр.

\begin{tabular}{|c|c|c|c|c|c|c|c|c|c|c|c|}
\hline \multirow{3}{*}{$\begin{array}{c}\text { Па- } \\
\text { ри } \\
\text { о3- } \\
\text { нак* }\end{array}$} & \multirow{3}{*}{$\begin{array}{c}\text { Напрям } \\
\text { схрещу- } \\
\text { вання }\end{array}$} & \multicolumn{6}{|c|}{ Батьківські форми } & \multicolumn{4}{|c|}{ Гібриди } \\
\hline & & \multicolumn{3}{|c|}{ пшениця } & \multicolumn{3}{|c|}{ спельта } & \multicolumn{2}{|c|}{ рослини $\mathrm{F}_{1}$} & \multicolumn{2}{|c|}{ рослини $\mathrm{F}_{2}$} \\
\hline & & $2009 \mathrm{p}$ & $2010 \mathrm{p}$. & $2011 \mathrm{p}$. & $2009 \mathrm{p}$ & $2010 \mathrm{p}$. & $2011 \mathrm{p}$ & 2009 p. & $2010 \mathrm{p}$. & $2010 \mathrm{p}$. & $2011 \mathrm{p}$. \\
\hline \multicolumn{12}{|c|}{ Героїня / UA0300111 (CAN) } \\
\hline \multirow{2}{*}{1} & пряме & \multirow{2}{*}{0,885} & \multirow{2}{*}{0,892} & \multirow{2}{*}{0,852} & \multirow{2}{*}{0,547} & \multirow{2}{*}{0,864} & \multirow{2}{*}{0,417} & 0,899 & 0,895 & $-0,806$ & 0,265 \\
\hline & обернене & & & & & & & 0,895 & 0,882 & 0,753 & 0,658 \\
\hline \multirow{2}{*}{2} & пряме & \multirow{2}{*}{0,529} & \multirow{2}{*}{0,258} & \multirow{2}{*}{0,458} & \multirow{2}{*}{0,816} & \multirow{2}{*}{0,601} & \multirow{2}{*}{0,715} & $-0,236$ & 0,756 & 0,799 & 0,711 \\
\hline & обернене & & & & & & & 0,113 & 0,772 & $-0,341$ & $-0,298$ \\
\hline \multirow{2}{*}{3} & пряме & \multirow{2}{*}{$-0,589$} & \multirow{2}{*}{0,383} & \multirow{2}{*}{0,392} & \multirow{2}{*}{0,252} & \multirow{2}{*}{0,636} & \multirow{2}{*}{0,375} & $-0,778$ & $-0,076$ & 0,782 & 0,582 \\
\hline & обернене & & & & & & & 0,462 & 0,198 & 0,175 & 0,389 \\
\hline \multirow[b]{2}{*}{4} & $\Pi$ & \multirow{2}{*}{$-0,413$} & \multirow{2}{*}{$-0,096$} & 0256 & 0268 & 0657 & 017 & $-0,664$ & 0,192 & 0,699 & 0,438 \\
\hline & обер & & & $-0,350$ & 0,508 & ו & $-0,1<0$ & 0,154 & $-0,125$ & 0,430 & 0,323 \\
\hline & & & & Sun & UA & 304 & & & & & \\
\hline 1 & пряме & 0859 & 0832 & 0789 & 0832 & 0811 & 0727 & 0,701 & 0,782 & 0,334 & 0,587 \\
\hline 1 & обернене & 0,059 & 0,052 & 0,109 & 0,052 & 0,011 & 0,121 & 0,779 & 0,713 & 0,855 & 0,831 \\
\hline 2 & пряме & 0803 & 0.419 & 0.524 & 0.468 & 0.526 & 01 & $-0,813$ & 0,773 & 0,522 & 0,323 \\
\hline 2 & обернене & $0,00 J$ & & & & & 0,1 & $-0,795$ & 0,708 & 0,618 & 0,458 \\
\hline 3 & $\Pi$ & 0833 & 0341 & 0452 & 0600 & 073 & 0 & 0,801 & 0,182 & 0,110 & 0,412 \\
\hline$J$ & обернене & & 0,041 & $0,+J 2$ & 0,099 & נוכו, & ו & $-0,810$ & 0,523 & $-0,084$ & 0,351 \\
\hline 4 & пр & 0779 & 0420 & 0389 & 0781 & 0664 & 0484 & 0,803 & 0,156 & $-0,018$ & 0,569 \\
\hline 4 & обернене & $0,1 / 9$ & 0,420 & 0,509 & 0,101 & 0,004 & 0,404 & $-0,785$ & 0,882 & 0,083 & 0,653 \\
\hline
\end{tabular}

Примітки: * - 1. Маса зерна з колоса - кількість зерен у колосі. 2. Маса зерна 3 колоса - маса 1000 зерен. 3. Маса зерна з колоса - кількість колосків у колосі. 4. Маса зерна з колоса - довжина колоса.

1000 зерен, що обумовлено стабільністю цього показника в межах популяції $\mathrm{F}_{1}$. У більш сприятливому 2010 р. збільшується маса 1000 зерен і залежність від неї продуктивності колосу. У 2009 р. суттєва негативна кореляція спостерігалась із кількістю колосків і довжиною колосу у прямій комбінації. Решта кореляцій були несуттєвими.

$\mathrm{y}$ рослин $\mathrm{F}_{2}$ чітко проявляються відмінності у характері взаємозв'язку залежно від напряму схрещування: якщо у прямій комбінації спостерігалися позитивні достовірні кореляції між масою зерна з колосу, з одного боку, і масою 1000 зерен, кількістю колосків у колосі і довжиною колоса, - 3 другого, то в оберненій комбінації зв'язки між цими ознаками були негативними або недостовірними. Отже, у рослин $\mathrm{F}_{2}$, де материнською формою взято спельту, продуктивність колоса визначається кількістю зерен у ньому, а у рослин $\mathrm{F}_{2}$, де за материнську форму використано пшеницю м'яку, продуктивність колоса здебільшого залежить від маси 1000 зерен, кількості колосків у колосі та корелює з його довжиною.

За схрещування сорту Sunnan зі спельтою
UA0300304 реципрокні відмінності за коефіцієнтами кореляції були менш вираженими. У рослин $\mathrm{F}_{1}$ зв'язок між масою зерна з колосу, з одного боку, та кількістю зерен із колосу, - 3 іншого, був високим і середнім у прямій та оберненій комбінаціях. Кореляція з масою 1000 зерен у прямій та оберненій комбінаціях також була досить високою, але у 2009 р., на відміну від 2010 р., від'ємною. Зв'язок маси зерна 3 колосу з кількістю колосків і довжиною колосу у 2009 р. був високим і в оберненій комбінації також від'ємним. У 2010 р. кореляції з цими ознаками були позитивними, але в оберненій комбінації значно вищими, ніж у прямій.

У $\mathrm{F}_{2}$ мала місце суттєва середня і висока кореляції маси зерна з колосу з озерненістю колосу i масою 1000 зерен. До того ж в оберненій комбінації коефіцієнт кореляції був значно вищим, аніж у прямій, і подібним до джерела цитоплазми - спельти. Решта кореляцій були нестабільними або недостовірними.

Пояснити зв'язок між продуктивністю колосу i кількістю колосків у колосі в $\mathrm{F}_{1}$ обох описаних пар комбінацій можна тим, що за несприятливих умов розподіл живильних речовин між більшою 
кількістю зернівок і пов'язане 3 цим зменшення їх маси має наслідком зменшення продуктивності колосу в цілому.

Відмінності між обома описаними парами комбінацій за взаємозв'язком ознак колосу (принаймні частково) обумовлені різницею двох сортів пшениці м'якої за крупністю зерна, пов'язаною 3 реакцією на умови вирощування: сорт Sunnan має зерно дрібніше за Героїню (табл. 1). Спельта більш стабільна за масою 1000 зерен, ніж пшениця м'яка, і досить стабільна за озерненістю колосу.

\section{Висновки:}

1. За масою зерна $з$ колосу спельта поступається пшениці м'якій у рік, сприятливий за умовами формування і наливу зернівки, і наближається до неї у несприятливий рік. Спельта характеризується стабільно підвищеною масою 1000 зерен, за рештою показників колосу вона в цілому поступається пшениці м'якій.

2. $\mathrm{Y} \mathrm{F}_{1}$ гібридів за ознаками колосу частіше за все мала місце гібридна депресія, рідше - неповне домінування однієї з батьківських форм. Гетерозис спостерігався у більш сприятливому році за масою 1000 зерен в обох реципрокних комбінаціях Sunnan / UA0300304 і у прямій комбінації Героїня / UA0300111; за масою зерна 3 колосу - у комбінації, де материнською формою $\epsilon$ пшениця м'яка Sunnan.

\section{БІБЛІОГРАФІЯ}

1. Воскресенская Г. С., Шиота В. И. Трансгресии признаков у гибридов BRASSIKA и методика количественного учета этого явления // Селекция и семеноводство. - 1967. - № 6. - С. 18-20.

2. Гончаров Н. П. Сравнительная генетика пшениц и их сородичей / Н. П. Гончаров. - Новосибирск, 2002. - 252 с.

3. Методические указания по изучению мировой коллекции пшеницы ; под ред. В. Ф. Дорофеева. - Л. : ВИР, 1977. - 28 с.

4. Пополнение, сохранение в живом виде и изучение мировой коллекции пшеницы, эгилопса и тритикале (Методические указания) / А. Ф. Мережко, Р. А. Удачин, В. Е. Зуев [та ін.]- Л. : СПб, ВИР, 1999. - 82 с.

5. Темирбекова $C$. K. Новые генетические источники устойчивости по зерновым культурам для
3. $\mathrm{У} \mathrm{F}_{2}$ гібридів між спельтою та пшеницею м'якою рослини, що перевищують кращу батьківську форму за всіма ознаками колоса, виявлені в усіх вивчених комбінаціях у рік, більш сприятливий за умовами зростання, на ранніх етапах розвитку рослин і посушливий - у другій половині вегетації. У рік із посушливими умовами на перших фазах вегетації і сприятливий у період наливу та формування зерна рослини 3 перевищенням виявлені лише у комбінації Героїня / UA0300111 за масою 1000 зерен; Sunnan / UA0300304 за довжиною колосу, UA0300304 / Sunnan за кількістю колосків і зерен у колосі.

4. Частота перевищення кращої батьківської форми за масою 1000 зерен була більшою, ніж за іншими ознаками, у комбінаціях, де материнською формою була спельта, й середньою - у реципрокних комбінаціях. Найбільші частота і ступінь перевищення кращої батьківської форми за продуктивністю колосу спостерігалися в обидва роки у комбінаціï Sunnan / UA0300304, найменші - у Героїня / UA0300111.

5. У гібридів між ярими спельтою та пшеницею м'якою маса зерна $з$ колосу тісно і стабільно пов'язана з озерненістю колосу в $\mathrm{F}_{1}$ реципрокних комбінацій і $\mathrm{F}_{2}$ комбінацій на цитоплазмі спельти. Зв'язок 3 іншими ознаками неоднозначний i залежить від напряму схрещувань і умов року.

использования в селекции / С. К. Темирбекова, И. М. Куликов, А. А. Курило // Зерновое хазяйство России. - 2010. - № 4. - С. 43-47.

6. Федин М. А. Генетика пшеницы и гетерозис / М. А. Федин. - М. : Колос, 1979. - 204 с.

7. Beil G. M. Inheritance of quantitative characters in grain sorghum / G. M. Beil, R. E. Atkins // Iova State Journal. - 1965. - № 39. - P. 3.

8. Griffing $B$. Analysis of quantitative gene-action by constant parent regression and related techniques / B. Griffing // Genetics. - 1950. - V. 35. - P. 303321.

9. McFadden E. S. The origin of Triticum spelta and its free threshing hexaploid relatives / E. S. McFadden E. S., Sears E. R. // J. Hered. - 1946. - V. 37. P. 107-116. 